University of Nebraska - Lincoln

DigitalCommons@University of Nebraska - Lincoln

Faculty Publications: Department of Entomology

Entomology, Department of

2012

\title{
Mortality Impact of MON863 Transgenic Maize Roots on Western Corn Rootworm Larvae in the Field
}

\author{
T. L. Clark \\ University of Missouri, Columbia and Monsanto \\ D. L. Frank \\ USDA-ARS, University of Missouri, Columbia \\ B. W. French \\ USDA-ARS, Wade.French@ars.usda.gov \\ Lance J. Meinke \\ University of Nebraska-Lincoln, Imeinke1@unl.edu \\ D. Moellenbeck \\ DM Crop Research, Polk City, IA, dan@dmcropresearch.com
}

See next page for additional authors

Follow this and additional works at: https://digitalcommons.unl.edu/entomologyfacpub

Part of the Agriculture Commons, Agronomy and Crop Sciences Commons, and the Entomology

Commons

Clark, T. L.; Frank, D. L.; French, B. W.; Meinke, Lance J.; Moellenbeck, D.; Vaughn, T. T.; and Hibbard, B. E., "Mortality Impact of MON863 Transgenic Maize Roots on Western Corn Rootworm Larvae in the Field" (2012). Faculty Publications: Department of Entomology. 528.

https://digitalcommons.unl.edu/entomologyfacpub/528

This Article is brought to you for free and open access by the Entomology, Department of at DigitalCommons@University of Nebraska - Lincoln. It has been accepted for inclusion in Faculty Publications: Department of Entomology by an authorized administrator of DigitalCommons@University of Nebraska - Lincoln. 


\section{Authors}

T. L. Clark, D. L. Frank, B. W. French, Lance J. Meinke, D. Moellenbeck, T. T. Vaughn, and B. E. Hibbard 


\title{
Mortality impact of MON863 transgenic maize roots on western corn rootworm larvae in the field
}

\author{
T. L. Clark $^{1,2}$, D. L. Frank ${ }^{3}$, B. W. French ${ }^{4}$, L. J. Meinke ${ }^{5}$, D. Moellenbeck ${ }^{6}$, T. T. Vaughn² \& B. E. Hibbard ${ }^{3}$ \\ 1 Division of Plant Science, University of Missouri, Columbia, MO, USA \\ 2 Monsanto Company, Chesterfield, MO, USA \\ 3 USDA-ARS, Plant Genetics Research Unit, 205 Curtis Hall, University of Missouri, Columbia, MO, USA \\ 4 USDA-ARS, Integrated Cropping System Research Unit, Brookings, SD, USA \\ 5 Department of Entomology, University of Nebraska, Lincoln, NE, USA \\ 6 DM Crop Research Group, Inc., Polk City, IA, USA
}

\section{Keywords}

Bacillus thuringiensis, Bt, Cry3Bb1, Diabrotica virgifera virgifera, insect resistance management

\section{Correspondence \\ Bruce Hibbard (corresponding author), Division of Plant Science, University of Missouri, 205 Curtis Hall, Columbia, MO 65211, USA. E-mail: \\ bruce.hibbard@ars.usda.gov}

This article reports the results of research only. Mention of trade names or commercial products in this publication is solely for the purpose of providing specific information and does not imply recommendation or endorsement by the US Department of Agriculture (USDA). USDA is an equal opportunity provider and employer.

Received: November 13, 2011; accepted: January 19, 2012.

doi: 10.1111/j.1439-0418.2012.01709.x

\begin{abstract}
Mortality of western corn rootworm (Diabrotica virgifera virgifera LeConte) due to feeding on MON863 transgenic maize (Zea mays L.) expressing the Cry3Bbl protein was evaluated at three Missouri sites in both 2003 and 2004 and at one site each in South Dakota, Nebraska and Iowa in 2004. To do this, survivorship relative to survivorship on isoline maize (i.e. the same genetic background, but without Cry3Bbl) was evaluated. Comparisons were made using low (1650-2500 eggs $/ \mathrm{m}$ ) and high (3300-3500 eggs/m) western corn rootworm egg densities. Significantly fewer beetles were recovered from MON863 than from isoline maize. Emergence from MON863 as a percentage of viable eggs ranged from $0.02 \%$ to $0.10 \%$, whereas percentage emergence from isoline maize ranged from $1.09 \%$ to $7.14 \%$. Survivorship on MON863 relative to survivorship on isoline averaged $1.51 \%$ when averaged across all environments and both years, so mortality because of the Cry3Bbl protein averaged $98.49 \%$. The average time delay to $50 \%$ cumulative beetle emergence from MON863 was 18.3 days later than from isoline maize. Females comprised $56 \%$ and $71 \%$ of total beetles recovered from MON863 in 2003 and 2004, respectively. Results are discussed in relation to insect resistance management (IRM) of western corn rootworm.
\end{abstract}

\section{Introduction}

The western corn rootworm, Diabrotica virgifera virgifera LeConte, is a major pest of maize, Zea mays L., in the United States and Europe (Gray et al. 2009). In the United States, transgenic maize hybrids that express Cry endotoxin proteins from the soil bacterium Bacillus thuringiensis Berliner $(\mathrm{Bt})$ have been developed to mitigate economic damage caused by corn rootworm larvae (Moellenbeck et al. 2001; Ellis et al. 2002; Vaughn et al. 2005; Walters et al. 2008, 2010). Transgenic maize expressing the Cry3Bbl protein (MON863) was registered for commercial sale in
2003, and two additional products expressing different proteins were registered for commercial sale in 2005 (Cry34/35Abl) and 2006 (mCry3A). No additional single proteins targeting rootworm have been registered, although the Cry3Bbl protein began transitioning from event MON863 to the MON88017 event after the latter was first registered for commercial sale in 2005.

The United States Environmental Protection Agency (EPA) has mandated that all registrants of $\mathrm{Bt}$ crops submit an insect resistance management (IRM) plan prior to registration. The goals of these IRM plans are to extend the lifetime of management 
options. The effectiveness of IRM plans depends on knowledge of many factors including mortality because of the toxin in question (Cry3Bbl in this case), frequently referred to as 'dose'. The 'highdose/refuge' strategy for IRM recommends planting Bt crops that produce a very high concentration of toxin (25 times the amount needed to kill 99\% of the susceptible insects), which should ensure that individuals that are heterozygous for resistance do not survive, making resistance functionally recessive (EPA 1998). Prior to registration of Bt maize for corn rootworms, most registrations of Bt crops in the United States were predicated on the use of a 'highdose/refuge' strategy for their primary target pests.

Mortality due to the mCry3A protein was $94.88 \%$ when averaged across six environments (Hibbard et al. 2010a). The average reduction in beetle emergence due to Cry34/35Abl proteins across three environments was $96.48 \%$ (Storer et al. 2006; see also Hibbard et al. 2010b). Although the reduction in beetle emergence due to eCry3.1Ab (not currently registered for commercial sale) was recently documented to be $99.79 \%$ (Hibbard et al. 2011), no individual proteins used in current rootworm transgenic products are expressed at the high-dose criteria of 25 -fold greater than that which would kill $99 \%$ of the susceptible insects.

Here, we report on field experiments to determine the mortality of western corn rootworm because of MON863 maize expressing the Cry3Bbl protein relative to survivorship on isoline maize (i.e. the same genetic background, but without Cry3Bbl) at three field sites in 2003 and six field sites in 2004. Comparisons were made at two different egg densities to better understand the role of density-dependent mortality (Hibbard et al. 2010b).

\section{Materials and Methods}

\section{Study sites and planting}

Mortality due to Cry3Bbl protein expression in MON863 transgenic maize was evaluated in 2003 and 2004 in a factorial randomized complete block design with two replications at each environment (location). Blocks consisted of four $3.05 \times 3.05 \mathrm{~m}$ plots each planted with MON863 or its near isoline (eight plots total per environment). Overall, methods were similar to those used in Hibbard et al. (2010a, 2011 ), except that two western corn rootworm infestation levels were used. The factors evaluated in the factorial design included maize treatment (MON863 and isoline), western corn rootworm infestation level
(1650 and 3300 eggs/m in 2003 and 2500 and 3500 eggs/m in 2004) and environment (three environments and soil types in 2003 and six environments and soil types in 2004).

In 2003, study sites were established at the University of Missouri, Bradford Research and Extension Center in Boone Co., MO, USA (Mexico silt loam comprised of $12.5 \%$ sand, $65 \%$ silt, and $22.5 \%$ clay); the University of Missouri, Hinkson Valley Farm in Boone Co., MO, USA (Haymond loam soil comprised of $50 \%$ sand, $38.5 \%$ silt, and $12.5 \%$ clay); and the University of Missouri, Greenley Research Center in Knox Co., MO, USA (Putnam silt loam comprised of 15\% sand, $62.5 \%$ silt, and $22.5 \%$ clay). In 2004, the Bradford Research and Extension Center and Hinkson Valley Farm were again used, but in different fields. The Knox Co. location was substituted with a private farm located in Lafayette Co., MO, USA (Marshall silt loam comprised of $15 \%$ sand, $67.5 \%$ silt and $17.5 \%$ clay), in 2004. In addition, a USDA-ARS research farm located in Brookings Co., SD, USA (Barnes clay loam comprised of $41 \%$ sand, $29 \%$ silt, and $31 \%$ clay); the University of Nebraska, Agricultural Research and Development Center located in Saunders Co., NE, USA (Aksarben silty clay loam comprised of $12.5 \%$ sand, $24.5 \%$ coarse silt, $25.2 \%$ fine silt, $3.4 \%$ very fine silt, and $34.4 \%$ clay); and private land located in Scott Co., IA (Tama clay loam $7.1 \%$ sand, $64.9 \%$ silt and $28 \%$ clay), were added to the study. At all study sites, the prior year's crop was soybean, Glycine max L. Central Missouri, South Dakota and Nebraska do not have the rotation-resistant variant of the western corn rootworm that oviposit outside of maize in soybeans and other crops, so we assumed that all western corn rootworm adults recovered were from eggs that we infested. Although similar assumptions were almost certainly true for plots located in Scott Co., Iowa, in 2004, this location may now have low levels of rotation-resistant populations (Gray et al. 2009).

All field sites in both years were planted by hand after rows were marked with a cleaned planter with $76.2-\mathrm{cm}$ row spacing. Individual $3.05 \times 3.05 \mathrm{~m}$ plots were four rows wide and were planted with either MON863 or its isoline at a rate of 6.56 seeds $/ \mathrm{m}$ (20 seeds/row or 80 seeds/plot). Any seed that did not germinate was replaced with extra plants transplanted and heavily watered at V1-V3 (Ritchie et al. 1992). To insure that western corn rootworm larvae would not move between plots, a $3.05 \mathrm{~m}$ buffer containing no vegetation was maintained between each plot within the four rows where plots were planted. In addition, four tractor-planted rows of commercial 'buffer' maize were planted on both sides of the study to help 
minimize wind damage to screen tents used in collection of adults from plots. Planting dates for each site are noted in Table 1. To ensure that all larvae were challenged by Cry3Bbl-expressing maize, all plants in the MON863 plots at each site were tested using gene check strips provided by Monsanto Corporation (QuickStix ${ }^{\mathrm{TM}}$ Strips for Cry3Bbl, EnviroLogix ${ }^{\mathrm{TM}}$, Portland, Maine). When a negative plant was detected, it was removed from the plot and replaced with a Cry3Bbl-expressing plant that was sown (at the same time) in nearby plots. Any transplanted plants were well watered to assure establishment. Cultural practices (e.g. tillage, fertilization, herbicide application) were typical of those recommended for agricultural procedures for each area (the Nebraska location was no-till), except that no insecticides (including seed treatments) were applied. When needed, all plots were hand weeded to ensure that they were kept weed free.

\section{Insects and infestation}

For each year of the study, infestation occurred approximately 2 week after planting when maize had reached the V2-V3 stage at each respective site (Table 1). In 2003, wild-type western corn rootworm eggs obtained from French Agricultural Research, Inc., Lamberton, MN, USA were mechanically infested at two rates $(\sim 1650$ and 3300 eggs $/ \mathrm{m})$ for both MON863 and its near isoline. Trenches $(5 \mathrm{~cm}$ deep) were dug on the sides of each row using hoes, and $50 \mathrm{ml}$ of egg solution was distributed evenly along the length of each side of each row with syringes. When the last of the $400 \mathrm{ml}$ egg/agar solution was gone, jars were rinsed with water and these eggs also placed within the plot in one of the trenches. Each respective plot received a total of either 20130 (low rate) or 40260 (high rate) viable western corn rootworm eggs. In 2004, western corn rootworm

Table 1 Important dates associated with the 2003 and 2004 field trials

\begin{tabular}{llll}
\hline Location & Planting & Infestation & Tent set-up \\
\hline Bradford, Boone Co., MO (2003) & 19 May & 30 May & 11 July \\
Hinkson, Boone Co., MO (2003) & 27 May & 9 June & 18 July \\
Knox Co., MO (2003) & 22 May & 5 June & 14 July \\
Bradford, Boone Co., MO (2004) & 11 May & 24 May & 12 July \\
Hinkson, Boone Co., MO (2004) & 17 May & 24 May & 12 July \\
Lafayette Co., MO (2004) & 12 May & 28 May & 16 July \\
Brookings Co., SD (2004) & 4 June & 21 June & 28 July \\
Saunders Co., NE (2004) & 27 April & 20 May & 12 July \\
Scott Co., IA (2004) & 12 May & 28 May & 17 July \\
\hline
\end{tabular}

J. Appl. Entomol. 136 (2012) 721-729 @ 2012 Blackwell Verlag, GmbH eggs obtained from the primary diapausing colony of the USDA-ARS laboratory in Brookings, SD, were infested at two rates $(\sim 2500$ and 3500 eggs $/ \mathrm{m})$ for both MON863 and its near isoline with each respective plot receiving either 31031 (low rate) or 42315 (high rate) viable western corn rootworm eggs. The Nebraska field sites were infested using a tractormounted egg infester, while the South Dakota and Iowa field sites were infested by hand using a volumetric flask with 10-ml applicator. All infestation rates mentioned above include only viable eggs determined in earlier laboratory hatch studies.

\section{Placement of screen tents and data collection}

At the onset of pupation ( 550-600 degree days after infestation), $3.7 \times 3.7 \mathrm{~m}$ insect-proof screen tents (Coleman Company, Inc., Wichita, KS, USA) were placed over each individual plot. The bottom edges of each tent were buried $8-12 \mathrm{~cm}$ below the soil surface to prevent beetle escape and help prevent wind damage. After tent placement, all maize plants were cut off at $10 \mathrm{~cm}$ above ground level except for two central plants that were left in each tent. These plants provided food for emerging beetles between collection dates and to concentrate beetles for collection. Beetles were collected two to three times weekly from individual tents using either mouth or battery operated aspirators (Catalogue \#s 1135A and 2820B, respectively; BioQuip, Rancho Dominguez, CA, USA). Upon collection, beetles were placed in individually labelled insect collecting chambers (BioQuip) and brought back to the laboratory where total beetle numbers, and gender was recorded for each respective emergence tent and location. Although not documented in 2003, emergence of beetles over time was recorded in 2004 .

\section{Data analysis}

Beetle numbers and percentage emergence data were analysed by year using the generalized linear mixed model of the SAS statistical package (PROC GLIMMIX; SAS Institute 2008). The statistical model contained the main plot effect of environment, the subplot effect of maize treatment (MON863 and isoline), the sub-subplot effect of infestation rate and all possible interactions. Replication within environment was included as the random statement, and all other variables were fixed. Least squares means (LSMEANS) of fixed effects were calculated separately for each year, and comparisons were made using the ADJUST $=$ TUKEY option of the LSMEANS 
statement. Results from all tests were considered statistically different at $\mathrm{P}<0.05$. For calculation of mortality due to Cry3Bbl, the percentage of beetles surviving MON863 at each egg density was divided by the average percentage surviving isoline in that environment at the lowest infestation level. The resulting survival rate was then subtracted from 1. Data were pooled by year and similarly analysed using PROC GLIMMIX with LSMEANS of fixed effects separated $(\mathrm{P}<0.05)$ using the TUKEY adjustment. Emergence rate of beetles from isoline maize at the lowest infestation rate was used for comparisons because density-dependent mortality would not occur at the lower egg density (Hibbard et al. 2010 b). In 2004, beetle emergence data were further analysed by plotting observed cumulative percentage emergence vs. ordinal dates. Data were averaged across environments, replications, infestation rates and beetle gender. PROC PROBIT of the SAS statistical package (SAS Institute 2008) was used to model the occurrence of $50 \%$ beetle emergence among MON863 and isoline maize at each infestation rate and the $95 \%$ confidence interval $(95 \% \mathrm{CI})$ of this point.

\section{Results}

The analysis showed that maize treatment and its interaction with environment had a significant effect on the number of western corn rootworm beetles recovered and percentage emergence for each year of the study (Table 2). Significantly more beetles were recovered from isoline maize than MON863 within each infestation level at each environment (Table 3). Emergence as a percentage of viable eggs ranged from $1.09 \%$ to $7.14 \%$ from isoline maize, whereas emergence as a percentage of viable eggs from MON863 ranged from $0.02 \%$ to $0.10 \%$ (Table 3 ). When averaged across both years and all environments, there was no significant difference in percentage emergence between the high infestation rate and low infestation rate for both the MON863 and isoline maize treatment. However, within an environment, percentage emergence of beetles on isoline maize at the lowest infestation rate was significantly greater than percentage emergence from isoline maize at the high infestation rate in the Hinkson Valley Farm location in 2003 and the South Dakota and Iowa locations in 2004 (Table 3), which suggests density-dependent mortality on isoline maize at the higher infestation level in these sites. For this reason, we compared percentage survivorship on Cry3Bbl with percentage survivorship on isoline
Table 2 ANOva table for factors impacting the number of western corn rootworm beetles recovered (top set) and their percent emergence (bottom set) in 2003 and 2004

\begin{tabular}{|c|c|c|c|c|c|c|}
\hline \multirow[b]{2}{*}{ Effect } & \multicolumn{3}{|c|}{2003} & \multicolumn{3}{|l|}{2004} \\
\hline & d.f. & $\mathrm{F}$ & $P$ & d.f. & $\mathrm{F}$ & $\mathrm{P}$ \\
\hline Treatment (Trt) & 1,9 & 214.24 & $<0.0001$ & 1,18 & 170.39 & $<0.0001$ \\
\hline Environment (Env) & 2,3 & 2.87 & 0.2014 & 5,6 & 7.25 & 0.0159 \\
\hline Trt $\times$ Env & 2,9 & 5.24 & 0.0310 & 5,18 & 7.67 & 0.0005 \\
\hline Infestation (Inf) & 1,9 & 33.44 & 0.0003 & 1,18 & 4.39 & 0.0505 \\
\hline Trt $\times \operatorname{Inf}$ & 1,9 & 31.30 & 0.0003 & 1,18 & 4.26 & 0.0538 \\
\hline Env $\times \operatorname{lnf}$ & 2,9 & 2.90 & 0.1068 & 5,18 & 1.38 & 0.2788 \\
\hline $\operatorname{Trt} \times \mathrm{Env} \times \operatorname{Inf}$ & 2,9 & 2.69 & 0.1214 & 5,18 & 1.34 & 0.2937 \\
\hline Treatment (Trt) & 1,9 & 881.43 & $<0.0001$ & 1,18 & 3850.37 & $<0.0001$ \\
\hline Environment (Env) & 2,3 & 11.76 & 0.0380 & 5,6 & 3.74 & 0.0698 \\
\hline Trt $\times$ Env & 2,9 & 14.71 & 0.0015 & 5,18 & 10.28 & $<0.0001$ \\
\hline Infestation (Inf) & 1,9 & 1.26 & 0.2899 & 1,18 & 3.31 & 0.0855 \\
\hline $\operatorname{Trt} \times \operatorname{Inf}$ & 1,9 & 0.00 & 0.9729 & 1,18 & 0.48 & 0.4978 \\
\hline Env $\times \operatorname{Inf}$ & 2,9 & 0.14 & 0.8677 & 5,18 & 13.78 & $<0.0001$ \\
\hline Trt $\times$ Env $\times \operatorname{Inf}$ & 2,9 & 4.06 & 0.0554 & 5,18 & 1.57 & 0.2177 \\
\hline
\end{tabular}

maize at the lower infestation rates, where densitydependent mortality was minimal (Hibbard et al. 2010b).

Western corn rootworm survivorship on MON863 relative to survivorship on isoline maize and the resulting mortality due to Cry3Bbl was significantly affected by environment $(\mathrm{F}=8.29$; d.f. $=8$, 9; $\mathrm{P}=0.0023)$, infestation rate $(\mathrm{F}=20.25 ;$ d.f. $=1$, 9; $\mathrm{P}=0.0015)$ and their interaction $(\mathrm{F}=3.52$; d.f. $=8$, 9; $\mathrm{P}=0.0393)$. Mortality due to the expression of MON863 varied from $96.84 \%$ to $99.79 \%$ depending on the environment and averaged $98.10 \%$ in 2003 and 98.68 in 2004 (Table 4). When averaged across both years and all environments, mortality due to MON863 averaged 98.49\% (Table 4).

When averaged across locations and beetle gender, there was more than an 18 days delay in time to $50 \%$ emergence from MON863 when compared with isoline maize (fig. 1). As the 95\% CI for estimated values for $50 \%$ emergence did not overlap between maize treatments, the emergence delay was statistically significant. Gender data were not recorded over time, so the delay in emergence between males and females is unknown. However, there was a trend towards female bias in total beetles recovered from MON863 in 2004. In 2003, $56 \%$ of beetles recovered from MON863 were female compared with $55 \%$ from isoline maize. In 2004, $71 \%$ of beetles recovered from MON863 were female compared with $56 \%$ from isoline maize. 
Table 3 Average number of western corn rootworm (WCR) beetles recovered and percent emergence on MON863 and isoline maize $(n=2)$ from two egg infestation rates at three environments in 2003 and six environments in 2004. Different lowercase letters indicated significant differences within a column and environment.

\begin{tabular}{|c|c|c|c|c|c|}
\hline Maize & $\begin{array}{l}\text { Infestation } \\
\text { level }^{1}\end{array}$ & $\begin{array}{l}\text { WCR/plot } \\
2003\end{array}$ & $\begin{array}{l}\text { \% Emergence } \\
2003\end{array}$ & $\begin{array}{l}\text { WCR/plot } \\
2004\end{array}$ & $\begin{array}{l}\text { \% Emergence } \\
2004\end{array}$ \\
\hline \multicolumn{6}{|c|}{ Bradford Research and Extension Center, Boone Co., MO } \\
\hline Isoline & Low & $570.5 b$ & 2.834 a & $1220.0 \mathrm{a}$ & $3.932 \mathrm{a}$ \\
\hline Isoline & High & 1250.5 a & $3.106 \mathrm{a}$ & 1797.5 a & $4.248 \mathrm{a}$ \\
\hline MON863 & Low & $16.0 \mathrm{c}$ & $0.080 \mathrm{~b}$ & $10.5 \mathrm{~b}$ & $0.034 b$ \\
\hline MON863 & High & $36.0 \mathrm{c}$ & $0.089 \mathrm{~b}$ & $11.0 \mathrm{~b}$ & $0.026 \mathrm{~b}$ \\
\hline \multicolumn{6}{|c|}{ Hinkson Valley Farm, Boone Co., MO } \\
\hline Isoline & Low & 484.0 a & $2.404 \mathrm{a}$ & 576.0 a & $1.856 \mathrm{a}$ \\
\hline Isoline & High & 700.5 a & $1.740 \mathrm{~b}$ & $898.5 \mathrm{a}$ & 2.123 a \\
\hline MON863 & Low & $1.0 \mathrm{~b}$ & $0.005 c$ & $2.0 \mathrm{~b}$ & $0.006 \mathrm{~b}$ \\
\hline MON863 & High & $4.0 \mathrm{~b}$ & $0.010 \mathrm{c}$ & $8.5 \mathrm{~b}$ & $0.020 \mathrm{~b}$ \\
\hline \multicolumn{6}{|c|}{ Environment $3, \mathrm{MO}^{2}$} \\
\hline Isoline & Low & $219.0 \mathrm{~b}$ & $1.088 \mathrm{~b}$ & $451.0 \mathrm{a}$ & $1.453 \mathrm{~b}$ \\
\hline Isoline & High & $896.0 \mathrm{a}$ & $2.226 \mathrm{a}$ & $1473.0 \mathrm{a}$ & $3.481 \mathrm{a}$ \\
\hline MON863 & Low & $6.0 \mathrm{c}$ & $0.030 \mathrm{c}$ & $5.0 \mathrm{~b}$ & $0.016 \mathrm{c}$ \\
\hline MON863 & High & $9.0 \mathrm{c}$ & $0.022 c$ & $11.0 \mathrm{~b}$ & $0.026 \mathrm{c}$ \\
\hline \multicolumn{6}{|c|}{ Brookings Co., SD } \\
\hline Isoline & Low & - & - & $2214.5 \mathrm{a}$ & $7.137 \mathrm{a}$ \\
\hline Isoline & High & - & - & $2221.0 \mathrm{a}$ & $5.249 b$ \\
\hline MON863 & Low & - & - & $45.0 \mathrm{~b}$ & $0.145 c$ \\
\hline MON863 & High & - & - & $41.0 \mathrm{~b}$ & $0.097 \mathrm{c}$ \\
\hline \multicolumn{6}{|c|}{ Saunders Co., NE } \\
\hline Isoline & Low & - & - & $447.0 \mathrm{a}$ & $1.441 \mathrm{~b}$ \\
\hline Isoline & High & - & - & $1071.5 \mathrm{a}$ & $2.532 \mathrm{a}$ \\
\hline MON863 & Low & - & - & $6.5 b$ & $0.021 \mathrm{c}$ \\
\hline MON863 & High & - & - & $16.5 \mathrm{~b}$ & $0.039 \mathrm{c}$ \\
\hline \multicolumn{6}{|c|}{ Scott Co., IA } \\
\hline Isoline & Low & - & - & 910.0 a & $2.933 \mathrm{a}$ \\
\hline Isoline & High & - & - & $528.0 \mathrm{a}$ & $1.248 \mathrm{~b}$ \\
\hline MON863 & Low & - & - & $13.5 \mathrm{~b}$ & $0.044 \mathrm{c}$ \\
\hline MON863 & High & - & - & $11.5 \mathrm{~b}$ & $0.027 c$ \\
\hline \multicolumn{6}{|c|}{ All environments by year } \\
\hline Isoline & Low & $424.5 \mathrm{~b}$ & $2.109 \mathrm{~b}$ & 969.8 a & $3.125 \mathrm{a}$ \\
\hline Isoline & High & 949.0 a & $2.357 \mathrm{a}$ & $1331.6 \mathrm{a}$ & $3.147 \mathrm{a}$ \\
\hline MON863 & Low & $7.7 \mathrm{c}$ & $0.038 \mathrm{c}$ & $13.8 \mathrm{~b}$ & $0.044 \mathrm{~b}$ \\
\hline MON863 & High & $16.3 \mathrm{c}$ & $0.041 \mathrm{c}$ & $16.6 \mathrm{~b}$ & $0.039 b$ \\
\hline \multicolumn{6}{|c|}{ All environments combined } \\
\hline Isoline & Low & - & - & $788.0 \mathrm{~b}$ & $2.786 \mathrm{a}$ \\
\hline Isoline & High & - & - & $1204.1 \mathrm{a}$ & $2.884 \mathrm{a}$ \\
\hline MON863 & Low & - & - & $11.7 \mathrm{C}$ & $0.042 b$ \\
\hline MON863 & High & - & - & $16.5 \mathrm{c}$ & $0.040 \mathrm{~b}$ \\
\hline
\end{tabular}

${ }^{1}$ Each respective plot received a total of 20130 (low rate) or 40260 (high rate) viable eggs in 2003 and 31031 (low rate) or 42315 (high rate) viable eggs in 2004.

${ }^{2}$ Environment 3; Knox Co. in 2003 and Lafayette Co. in 2004.

\section{Discussion}

Although current models serve as a framework to understand the fundamental processes important to the evolution of insect resistance in the western corn rootworm (Storer 2003; Crowder et al. 2006; Onstad 2006; Onstad and Meinke 2010), they ultimately represent an abstraction of a much more complex ecological reality. For this reason, the context of resistance development is often local, scale dependent and diffi- cult to predict (Durrett and Levin 1994). Models also require accurate empirical data for relevance. In the current study, maize expressing Cry3Bbl from the MON863 event caused an average reduction in western corn rootworm beetle emergence relative to emergence from isoline maize of $98.49 \%$. Data from this study enable a relative comparison to be made of the mortality due to Cry3Bbl to other rootworm-active proteins that have been evaluated in field experiments using a similar experimental design (i.e. mCry3A: 
Table 4 Survival on MON863 relative to survival on isoline at the lowest egg infestation rate and resulting selection intensity of MON863 across three environments in 2003 and six environments in 2004. Different lowercase letters indicated significant differences within a column and environment.

\begin{tabular}{|c|c|c|c|c|}
\hline $\begin{array}{l}\text { Infestation } \\
\text { level }\end{array}$ & $\begin{array}{l}\text { Rel. surv. } \\
\text { (\%) } 2003\end{array}$ & $\begin{array}{l}\text { Sel. int. } \\
(\%) 2003\end{array}$ & $\begin{array}{l}\text { Rel. surv. } \\
\text { (\%) } 2004\end{array}$ & $\begin{array}{l}\text { Sel. int. } \\
\text { (\%) } 2004\end{array}$ \\
\hline \multicolumn{5}{|c|}{ Bradford Research and Extension Center, Boone Co., MO } \\
\hline Low & $2.80 \mathrm{a}$ & $97.20 \mathrm{a}$ & 0.86 a & $99.14 \mathrm{a}$ \\
\hline High & $3.16 \mathrm{a}$ & $96.84 \mathrm{a}$ & $0.66 \mathrm{a}$ & $99.34 \mathrm{a}$ \\
\hline \multicolumn{5}{|c|}{ Hinkson Valley Farm, Boone Co., MO } \\
\hline Low & $0.21 \mathrm{a}$ & 99.79 a & $0.35 \mathrm{a}$ & $99.65 \mathrm{a}$ \\
\hline High & $0.41 \mathrm{a}$ & 99.59 a & $1.08 \mathrm{a}$ & $98.92 \mathrm{a}$ \\
\hline \multicolumn{5}{|c|}{ Environment $3, \mathrm{MO}^{1}$} \\
\hline Low & $2.74 \mathrm{a}$ & $97.26 \mathrm{a}$ & $1.11 \mathrm{a}$ & 98.89 a \\
\hline High & $2.05 \mathrm{a}$ & 97.95 a & $1.79 \mathrm{a}$ & $98.21 \mathrm{a}$ \\
\hline \multicolumn{5}{|c|}{ Brookings Co., SD } \\
\hline Low & - & - & $2.03 \mathrm{a}$ & $97.97 \mathrm{a}$ \\
\hline High & - & - & $1.36 \mathrm{a}$ & $98.64 \mathrm{a}$ \\
\hline \multicolumn{5}{|c|}{ Saunders Co., NE } \\
\hline Low & - & - & $1.45 \mathrm{a}$ & 98.55 a \\
\hline High & - & - & $2.71 \mathrm{a}$ & $97.29 \mathrm{a}$ \\
\hline \multicolumn{5}{|c|}{ Scott Co., IA } \\
\hline Low & - & - & $1.48 \mathrm{a}$ & $98.52 \mathrm{a}$ \\
\hline High & - & - & 0.93 a & $99.07 \mathrm{a}$ \\
\hline \multicolumn{5}{|c|}{ All environments by year } \\
\hline Mean & 1.90 & 98.10 & 1.32 & 98.68 \\
\hline \multicolumn{5}{|c|}{ All environments combined } \\
\hline Mean & & & 1.51 & 98.49 \\
\hline
\end{tabular}

${ }^{1}$ Environment 3; Knox Co. in 2003 and Lafayette Co. in 2004.

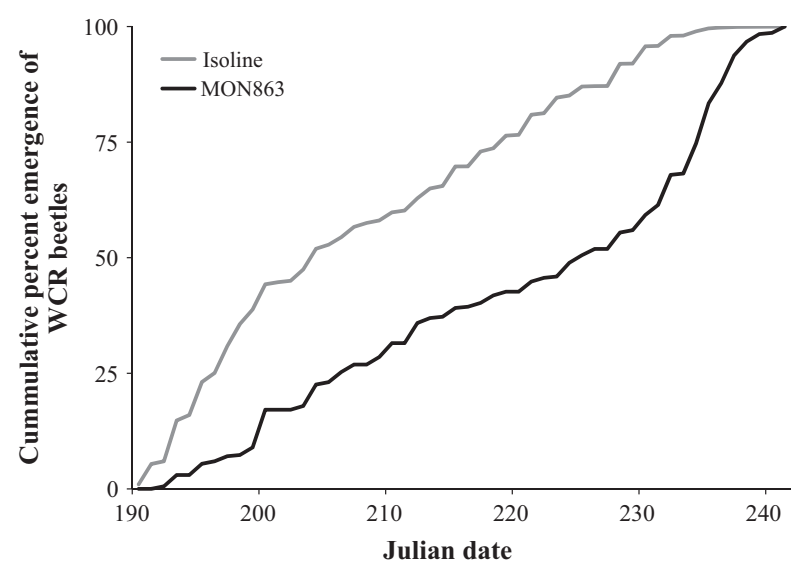

Fig. 1 Cumulative percentage emergence of western corn rootworm beetles by Julian date for 2004 averaged across two replications and two infestation rates in six environments. Total emergence for the MON863 and isoline maize treatments was 368 and 27584 beetles, respectively.

Hibbard et al. 2010a; Cry34/35Abl: Storer et al. 2006; Hibbard et al. 2010b; eCry3.1Ab: Hibbard et al. $2011)$.
Under laboratory and greenhouse conditions, selected western corn rootworm populations have developed resistance to Cry34/35Abl, Cry3Bbl and mCry3A (Lefko et al. 2008; Meihls et al. 2008, 2011; Meihls 2010; Oswald et al. 2011). To deter resistance development in the field, initial IRM plans for corn rootworms required a $20 \%$ block or strips of non-Bt maize planted within or adjacent to the rootwormactive Bt maize. This same basic plan was used for the first three registrations (Cry3Bbl, Cry34/35Abl and mCry3A). A pyramid of Cry3Bbl and Cry34/35Abl, plus Lepidopteran and herbicide tolerance genes (SmartStax $^{\mathrm{TM}}$ maize, developed through a collaboration of Monsanto Company, St. Louis, MO, USA and DowAgrosciences, Indianapolis, IN, USA) was registered with just a $5 \%$ block or strip rootworm refuge within or adjacent to the Bt maize (EPA 2009). In addition, a seed blend refuge was recently registered for the first time, which is composed of a $10 \%$ blend of non-Bt seed within the seed bag that serves as the refuge seed for Cry34/35Abl (EPA 2010). The landscape of rootworm products, refuge size and refuge type is changing quickly, and it is likely that more changes can be expected soon. For instance, Smarts$\operatorname{tax}^{\mathrm{TM}}$ maize has also now been registered as a seed blend, but with a 5\% non-Bt blend (EPA 2011a) and a pyramid of mCry3A + Cry34/35Abl (along with Lepidoptera and herbicide-targeted genes) also recently received EPA registration for commercial sale (EPA 201lb). Finally, a modified Bt protein, eCry3.1 Ab (Walters et al. 2010; Hibbard et al. 2011) and double stranded RNA which trigger RNA interference (Baum et al. 2007) are also both currently being targeted for future commercialization. Empirical data will also be needed for each of these products to develop an optimized resistance management plan to delay the onset of widespread field resistance.

Field resistance to Cry $3 \mathrm{Bb} 1$ has recently been documented in specific fields with prolonged use of MON863 and MON88017 (Gassmann et al. 2011). Growers in these 'problem fields' had planted Cry3Bbl-expressing corn for up to 6 years without rotation, but growers were not asked whether or not they planted $20 \%$ non-Bt corn adjacent or within the affected fields as required. Given that resistance had developed in the laboratory in nine of nine laboratory selection experiments to Cry3Bbl-expressing corn within just a few generations of selection (Meihls et al. 2008; Meihls 2010; Oswald et al. 2011), it is not surprising resistance has apparently also been selected for in specific fields with a long history of planting Cry3Bbl-expressing corn, especially if refuge corn was not planted. These situations document 
the importance of complying with resistance management requirements for rootworm-targeted products.

In our study, we found an 18-days delay in time to $50 \%$ emergence from Cry $3 \mathrm{Bb}$-expressing maize compared with isoline maize. Murphy et al. (2010) documented a delay in initial emergence of western corn rootworm beetles from MON863 maize vs. isoline that also exceeded 2 weeks. The nonsynchronous emergence of beetles from refuge fields and $\mathrm{Bt}$ fields could contribute to resistance, in part, because mating ability of western corn rootworm males declines rapidly with beetle age (Kang and Krupke 2009), and susceptible males from refuge maize might not be available to mate with late emerging females from Bt maize. Delay in 50\% emergence from Cry34/35Abl was apparently much shorter and averaged 7 days (Storer et al. 2006), while delay in $50 \%$ emergence due to eCry3.1Ab and eCry3.1Ab + mCry3A averaged 8 and 4.6 days, respectively (Hibbard et al. 2011).

None of the registered individual Bt proteins targeted towards corn rootworm express a concentration of Cry proteins that is truly high-dose (see EPA 2002; Storer et al. 2006, Hibbard et al. 2010a,b; and Hibbard et al. 2011), but root protection from western corn rootworm larval damage due to Bt maize is usually as good as or better than is possible with any insecticide. Significant corn rootworm damage may still occur under very high rootworm pressure (Gray et al. 2007). Reduced levels of extractable Cry3Bbl protein later in the season (Vaughn et al. 2005) have also been proposed as a mechanism to explain late season damage. However, data from Hibbard et al. (2009) and Frank et al. (2011) do not support this hypothesis. Damage to, larval recovery from, and adult emergence from Cry3Bbl and mCry $3 \mathrm{~A}$ did not significantly differ between widely varying egg hatch times and maize phenologies.

In summary, survivorship of western corn rootworm larvae on Cry3Bbl-expressing maize from the MON863 event averaged $1.51 \%$ relative to survivorship on isoline maize. Survivorship at both infestation levels on MON863 was compared with survivorship on isoline at the lower infestation level, where any density-dependent mortality would be minimal (Hibbard et al. 2010b). Mortality due to Cry3Bbl-expressing maize was $98.49 \%$ when averaged across nine environments in four states. In addition to the value of these data for resistance management models, because these data were collected prior to the widespread use of this product, they can be used as a baseline for understanding possible resistance to $\mathrm{Cry} 3 \mathrm{Bbl}$ in future studies.

\section{Acknowledgements}

We thank Matt Higdon (USDA-ARS), Arnulfo (Tony) Antonio (USDA-ARS), Dave Beck (USDA-ARS), Jim Brown (University of Nebraska), Bill McCormick (University of Nebraska) and a number of temporary summer labourers for assistance in setting up the trials and counting and sexing beetles. Funding for this work was provided by Monsanto Company.

\section{References}

Baum JA, Bogaert T, Clinton W, Heck GR, Feldmann P, Illagan O, Johnson S, Plaetinck G, Munyikwa T, Pleau M, Vaughn T, Roberts J, 2007. Control of coleopteran insect pests through RNA interference. Nat. Biotech. 25, 1322-1326.

Crowder DW, Onstad DW, Gray ME, 2006. Planting transgenic insecticidal corn based on economic thresholds: consequences for integrated pest management and insect resistance management. J. Econ. Entomol. 99, 899-907.

Durrett R, Levin S, 1994. The importance of being discrete (and spatial). Theor. Popul. Biol. 46, 363-394.

Ellis RT, Stockhoff BA, Stamp L, Schnepf HE, Schwab GE, Knuth M, Russell J, Cardineau GA, Narva KE, 2002. Novel proteins active on western corn rootworm, Diabrotica virgifera virgifera LeConte. Applied \& Environ. Microbio. 68, 1137-1145.

EPA, 1998. The environmental protection agency's white paper on Bt plant-pesticide resistance management. Environmental Protection Agency, Washington, DC, USA.

EPA, 2002. Corn rootworm plant-incorporated protectant non-target insect and insect resistance management issues, part B: insect resistance management issues. Scientific advisory panel. [WWW document]. URL http:// www.epa.gov/scipoly/sap/meetings/2002/august/ august2002final.pdf [accessed on February 2012].

EPA, 2009. Pesticide fact sheet. [WWW document]. URL http://www.epa.gov/oppbppd l/biopesticides/pips/ smartstax-factsheet.pdf [accessed on February 2012].

EPA, 2010. Biopesticides registration action document. [WWW document]. URL http://www.epa.gov/oppbppd1/biopesticides/pips/bt-seed-blends.pdf [accessed on February 2012].

EPA, 2011 la. Biopesticides registration action document: MON $89034 \times$ TC1507 × MON $88017 \times$ DAS-59122-7 (SmartStax) B.t. corn seed blend. [WWW document]. 
URL http://www.regulations.gov/\#!docketDetail;dct= FR\%252BPR\%252BN\%252BO\%252BSR;rpp=10;po= 0;D=EPA-HQ-OPP-2011-0362 [accessed on February 2012].

EPA, $2011 \mathrm{~b}$. Biopesticides registration action document: Btl $1 \times$ DAS-59122-7 × MIR604 × TCI507 Corn. [WWW document]. URL http://www.kellysolutions. com/erenewals/documentsubmit/KellyData\%5CGA\% 5Cpesticide\%5CMSDS\%5C67979\%5C67979-17\% 5C67979-17_BT11_X_DAS_59122_7_X_MIR604_X _TC1507_CORN_ALTERNATE_BRAND_NAME_ AGRISURE_3122_8_16_2011_11_10_07_AM.pdf [accessed on February 2012].

Frank DL, Bukowsky R, French BW, Hibbard BE, 2011. Effect of MIR604 transgenic maize at different stages of development on western corn rootworm (Coleoptera: Chrysomelidae) in a Central Missouri field environment. J. Econ. Entomol. 104, 2054-2061.

Gassmann AJ, Petzold-Maxwell JL, Keweshan RS, Dunbar MW, 2011. Field-evolved resistance to Bt maize by western corn rootworm. PLoS One 6, e22629.

Gray ME, Steffey KL, Estes RE, Schroeder JB, 2007. Responses of transgenic maize hybrids to variant western corn rootworm larval injury. J. Appl. Entomol. 131, 386-390.

Gray ME, Sappington T, Miller NJ, Moeser J, Bohn MO, 2009. Adaptation and invasiveness of western corn rootworm: intensifying research on a worsening pest. Annu. Rev. Entomol. 54, 303-321.

Hibbard BE, El Khishen AA, Vaughn TT, 2009. Impact of MON863 transgenic roots is equivalent on western corn rootworm larvae for a wide range of maize phenologies. J. Econ. Entomol. 102, 1607-1613.

Hibbard BE, Clark TL, Ellersieck MR, Meihls LN, El Khishen AA, Kaster V, York-Steiner H, Kurtz R, 2010 a. Mortality of western corn rootworm larvae on MIR604 transgenic maize roots: field survivorship has no significant impact on survivorship of Fl progeny on MIR604. J. Econ. Entomol. 103, 2187-2196.

Hibbard BE, Meihls LN, Ellersieck MR, Onstad DW, 2010b. Density-dependent and density-independent mortality of the western corn rootworm: impact on dose calculations of rootworm-resistant Bt corn.

J. Econ. Entomol. 103, 77-84.

Hibbard BE, Frank DL, Kurtz R, Boudreau E, Ellersieck MR, Odhiambo JF, 2011. Mortality impact of Bt transgenic maize roots expressing eCry3.1 Ab, mCry3 $\mathrm{A}$, and eCry3.1Ab+mCry $3 \mathrm{~A}$ on western corn rootworm in the field. J. Econ. Entomol. 104, 1584-1591.

Kang J, Krupke CH, 2009. Likelihood of multiple mating in Diabrotica virgifera virgifera (Coleoptera: Chrysomelidae). J. Econ. Entomol. 102, 2096-2100.

Lefko SA, Nowatzki TM, Thompson SD, Binning RR, Pascual MA, Peters ML, Simbro EJ, Stanley BH, 2008.
Characterizing laboratory colonies of western corn rootworm (Coleoptera: Chrysomelidae) selected for survival on maize containing event DAS-59122-7. J. Appl. Entomol. 132, 189-204.

Meihls LN, 2010. Development and Characterization of Resistance to Transgenic Corn in Western corn Rootworm. Ph.D. Dissertation. University of Missouri, Columbia, MO, USA, pp. 111.

Meihls LN, Higdon ML, Siegfried BD, Spencer TA, Miller NK, Sappington TW, Ellersieck MR, Hibbard BE, 2008. Increased survival of western corn rootworm on transgenic corn within three generations of on-plant greenhouse selection. Proc. Nat. Acad. Sci. 105, 19177-19182.

Meihls LN, Higdon ML, Ellersieck MR, Hibbard BE, 2011. Selection for resistance to mCry3A-expressing transgenic corn in western corn rootworm. J. Econ. Entomol. 104, 1045-1054.

Moellenbeck DJ, Peters ML, Bing JW, Rouse JR, Higgins LS, Sims L, Nevshemal T, Marshall L, Ellis RT, Bystrak PG, Lang BA, Stewart JL, Koubak K, Sondag V, Gustafson V, Nour K, Xu DP, Swenson J, Zhang J, Czapla T, Schwab G, Jayne S, Stockhoff BA, Narva K, Schnepf HE, Stelman SJ, Poutre C, Koziel M, Duck N, 2001. Insecticidal proteins from Bacillus thuringiensis protect corn from corn rootworms. Nat. Biotechnol. 19, 668-672.

Murphy AF, Ginzel MD, Krupke CH, 2010. Evaluating western corn rootworm (Coleoptera: Chrysomelidae) emergence and root damage in a seed mix refuge. J. Econ. Entomol. 103, 147-157.

Onstad DW, 2006. Modeling larval survival and movement to evaluate seed mixtures of transgenic corn for control of western corn rootworm (Coleoptera: Chrysomelidae). J. Econ. Entomol. 99, 1407-1414.

Onstad DW, Meinke LJ, 2010. Modeling evolution of Diabrotica virgifera virgifera (Coleoptera: Chrysomelidae) to transgenic corn with two insecticidal traits. J. Econ. Entomol. 103, 849-860.

Oswald KJ, French BW, Nielson C, Bagley M, 2011. Selection for Cry $3 \mathrm{Bbl}$ resistance in a genetically diverse population of nondiapausing western corn rootworm (Coleoptera: Chrysomelidae). J. Econ. Entomol. 104, 1038-1044.

Ritchie SW, Hanway JJ, Benson GO, 1992. How a corn plant develops. Iowa State University, Ames, IA.

SAS Institute, 2008. SAS 9.1.3 help and documentation. SAS Institute, Cary, NC.

Storer NP, 2003. A spatially explicit model simulating western corn rootworm (Coleoptera: Chrysomelidae) adaptation to insect-resistant maize. J. Econ. Entomol. 96, 1530-1547.

Storer NP, Babcock JM, Edwards JM, 2006. Field measures of western corn rootworm (Coleoptera: Chrysomelidae) mortality caused by Cry34/35Ab1 proteins expressed in maize event 59122 and 
implications for trait durability. J. Econ. Entomol. 99, 1381-1387.

Vaughn T, Cavato T, Brar G, Coombe T, DeGooyer T, Ford S, Groth M, Howe A, Johnson S, Kolacz K, Pilcher C, Purcell J, Romano C, English L, Pershing J, 2005. A method of controlling corn rootworm feeding using a Bacillus thuringiensis protein expressed in transgenic maize. Crop Sci. 45, 931-938.

Walters FS, Stacy CM, Lee MK, Palekar N, Chen JS,

2008. An engineered chymotrypsin/cathepsin G site in domain I renders Bacillus thuringiensis Cry3 A active against western corn rootworm larvae. Appl. Environ. Microbiol. 74, 367-374.

Walters FS, deFontes CM, Hart H, Warren GW, Chen JS, 2010. Lepidopteran-active variable-region sequence imparts Coleopteran activity in eCry3.1Ab, an engineered Bacillus thuringiensis hybrid insecticidal protein. Appl. Environ. Microbiol. 76, 3082-3088. 